\title{
BRIDGE PIER SCOUR EVALUATION IN MEANDERING CHANNELS
}

\author{
Gamal Elsaeed $^{1 *}$, Hossam Elsersawy ${ }^{2}$, Mohammad Ibraheem ${ }^{3}$, Fatma Samir ${ }^{4}$ \\ $1 *$ Professor of Hydraulics and Water Resources, Faculty of Engineering, Shobra, Banha University, Cairo, Egypt. \\ ${ }^{2}$ Assistant Professor, Nile Research Institute, National Water Research Center, Delta Barrage, Egypt. \\ ${ }^{3}$ Lecturer, Faculty of Engineering, Shobra, Banha University, Cairo, Egypt. \\ ${ }^{4}$ Assistant Researcher, Nile Research Institute, National Water Research Center, Delta Barrage, Egypt.
}

*Corresponding Author: -

Email: gelsaeed@feng.bu.edu.eg

\begin{abstract}
: -
The objectives of this research are to predict and evaluate the effect of releasing high/extreme flow discharges on scour at 13 bridge piers of (3) bridges located at Kafr El-Zayat City. Field data, empirical equations and a two-dimensional model were used. The empirical equations were used to predict the general, contraction and bend scour of the bed's morphological changes along the entire reach of the Rosetta Branch.

The 2-D model was used to predict scour at the bridge piers in the study area considering two scenarios of high river discharges. The expected extending of the scour holes around the main piers was also predicted. The results showed that in case the released discharges were $\left(69.90,220.00 \mathrm{~m} . \mathrm{m}^{3} /\right.$ day), the total scour around piers evaluated at the (3) bridges were $(13.98,17.74 m)$ for bridge No. (1), (10.33, 13.93m) for bridge No. (2) and (12.64, 15.34m) for bridge No. (3). It is recommended to follow up the geometry of the scour holes after one year of passing extreme high discharges.
\end{abstract}

Keywords: High Discharges, Rosetta Branch, Local Scour, Numerical Models, Kafr El-Zayat Bridges, Bridge Piers. 


\section{INTRODUCTION}

During extreme high discharges, greater discharges than the annual maximum were released. These peak discharges caused local scour in the vicinity of bridges, harbors and other structures and inundation to former flood plains that are currently in use.

The Nile River is relatively straight with some sinuous reaches over short distances that are related to steeper bed slopes. The increase in sinuosity in turn increases the bed slope more than $10 \mathrm{~cm} / \mathrm{km}$. Steeper portions become more active and bank erosive. Consequently, scouring action was expected to continue in these areas. The meander wavelengths of the River Nile varied from $2500 \mathrm{~m}$ to $4500 \mathrm{~m}$. The meander pattern was subsequent to the construction of the High Aswan Dam (H.A.D.) as a result of a reduction in discharge and sediment load. After constructing H.A.D, the Nile was considered as a very low energy river with low water surface gradients. From the Aswan Dam to the head of the Nile Delta, the river distance is about $950 \mathrm{~km}$, and the river bed drops ranging from $+79 \mathrm{~m}$ to $+11 \mathrm{~m}$, giving rise to an average slope of $7.2 \mathrm{~cm} / \mathrm{km}$. The average bed slope along the Damietta and Rosetta Branches of the Nile Delta (240km from Delta Barrage, (Fig. 1)) was $5.6 \mathrm{~cm} / \mathrm{km}$. The suspended bed material loads for the Nile downstream Aswan has changed substantially as a result of the creation of Lake Nasser HRI [1].

The released water from Aswan Dam was kept as far as possible equal to the water demand, leaving no surplus water to be wasted into the sea except during the winter closure period and in emergency cases belonging to the decided regulations of the HAD. High discharges released from HAD were determined according to the regulation guidelines for operating the HAD. These extreme discharges cause damages to the water control structures along the Nile and its branches. Relatively high discharges cause local scour near bridges, harbors and other structures.

Also, relatively high discharges cause inundation to

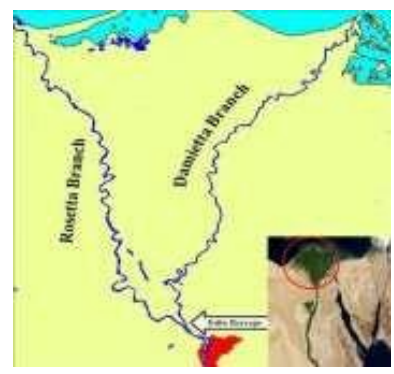

Fig. 1. Rosetta and Damietta branches

former flood plains currently in use. Such inundation in turn ruins agricultural properties, urban areas, and roads and may expose human lives to danger.

\section{LITERATURE REVIEW}

The RNDP Project [2] has accomplished a comprehensive analysis of the fluvial characteristics of the River Nile. Before the construction of H.A.D., the peak flows were quite regular down the river but after building H.A.D., the peak flow decreases significantly downstream as irrigation water is withdrawn. During extreme high floods, higher discharges than the annual maximum discharge in an average year may be released. Associated high discharges cause local scour near bridge piers, especially the wide area. Meander migration is a process in which water flow erodes soil on one bank and deposits it on the opposite bank. Therefore, a gradual shift of bank line occurs over the long term. Bank erosion undermines bridge piers and abutments, scours the foundations of parallel highways, and causes loss of useful land, according to [3].

Scour is the result of the erosive action of flowing water, excavating and carrying away material from the bed and banks of streams and from around the piers and abutments of bridges, [4]. It is considered one of the main factors affecting the stability of the bridges. (Fig. 2) shows flow profile around a circular bridge pier, [4]

Local Scour is defined as the erosion due to redirected and contracted flow lines around piers or abutments [5]. The evaluation of local scour was developed by [6] and procedure set in [4]. Local scour is caused by flow obstruction and impingement - most local scour caused by man-made structures such as bridge piers, bridge abutment, culverts, grade control, and drop structures. The factor of safety for local scour is basely 1.3 [5], but it may be reduced to 1.0 due to excessive calculated local scour, [7]. There are many local scour depth prediction equations considered in the literature as well as a number of review studies that used the comparison [4] techniques between different equations and methodologies involved in scour prediction. [8] measured mean flow directions, magnitude, and turbulent flow fluctuations and computed turbulent power spectra around a circular pile for flatbed, intermediate, and equilibrium scour holes. He found that a strong vertical downward flow developed ahead of the cylinder as the scour hole enlarged. The size and circulation of the horseshoe vortex increased rapidly, and the velocity near the hole bottom decreased as the scour hole was enlarged.

As the scour hole develops further, the intensity of the vortex decreases and reaches a constant value at the equilibrium stage. Large scour holes may also develop downstream from piers under certain circumstances (e.g. [9]). More recently another potential scour mechanism was identified [10]. This mechanism resulted from the pressure gradient field generated by the presence of the structure in the flow. [11] collected new long-duration clear-water scour data for single cylindrical piers with the objective of investigating the effect of sediment coarseness on the equilibrium scour depth and improving the scour depth time evolution modeling by using the exponential function suggested in the literature. 
The effect of a single-peaked flood wave on pier scour was investigated theoretically and experimentally by [12]. The conditions considered involve clear-water scour of a cohesion-less material for a given median sediment size and sediment non-uniformity. An approach flow characterized by a flow depth and velocity, a circular-shaped cylindrical bridge pier, and a flood hydrograph defined by its time to peak discharge. Sheppard et al. [13], employed twenty-three of the more recent and commonly used equilibrium local scour equations for cohesion-less sediments which were evaluated using compiled laboratory and field databases. Because the maturity of the scour hole at the time of measurement for the field data was unknown, they were only used to evaluate under prediction by the equations. A preliminary quality control screening of the equilibrium scour methods/equations reduced the number of equations from the initial 23 to 17 . The remaining 17 methods/equations were analyzed using laboratory and field data.

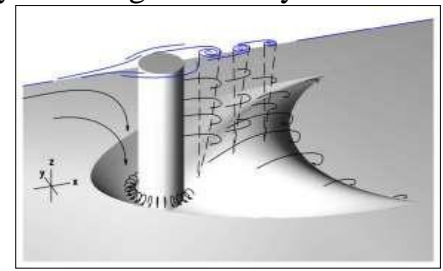

Fig. 2. Flow profile around a circular bridge pier

Contraction scour is located at the flow area of the river that is reduced due to the bridge construction. The contraction scour evaluation was developed by Federal Highway Administration criteria. The higher value between the contraction scour equation in this section and Neill's general scour equation (Equation (5) next page) could be used for this component [5]. If there is a bend, then the higher value between

Neill's equation with a bend and the contraction scour equation and the bend scour equation could be used. The following equation (for critical velocity) can be used to determine the contraction scour if the flow upstream of the bridge is clearwater or live-bed [6]. The equation has the following form:

$$
V_{c}=11.17 y_{a}^{\frac{1}{6}} D_{50}^{\frac{1}{3}}
$$

Clear-water when $\mathrm{Vc}>$ mean velocity, Live-bed when $\mathrm{Vc}<$ mean velocity.

See Section (9) (List of Symbols) for the definition of the symbols used in this section and the paper.

Live-bed Contraction Scour Determination

$$
\frac{y_{2}}{y_{1}}=\left[\frac{Q_{2}}{Q_{1}}\right]^{\frac{0}{7}}\left[\frac{W_{1}}{W_{2}}\right]^{x} \quad y_{s}=y_{2}-y_{0}
$$

Clear-water Contraction Scour

$$
Y_{2}=\left[\frac{0,00 \% \pi Q^{2}}{D_{m}^{\frac{2}{3}} w^{2}}\right]^{\frac{3}{3}} \quad Y_{s}=y_{2}-y_{0}
$$

Bend scour is concentrated near the outside of the bend resulting from stream plan form characteristics and scour at confluences [5]. The equation has the form [14]:

$$
Z_{\text {bs }}=\frac{0.0685 y V^{0.8}}{r_{b .}^{0.4 g^{3}}}\left[2.1\left(\frac{\sin ^{2}\left(\frac{a}{a}\right)}{\cos a}\right)^{0.2}-1\right]
$$

The general scour component is the scour caused by the passage of one flood. The Flood Control District of Maricopa County [7] uses three general scour equations: Lacey's Equation, Neill's Equation and Blench's Equation, [15]. Neill's Equation is applicable to streams where there is constriction of the channels due to bridges or other structures. The equation has the form [15]:

$$
y_{g s}=Z d_{f}=Z d_{i}\left(\frac{q f}{q_{i}}\right)^{m}
$$

The wide pier problem is considered to be a concern when the relative depth, $y / b$, is too small to allow the vortices to fully develop where $y$ is the flow depth and $b$ is the pier width. Earlier investigations of the dependence of scour depth on $y / b$ were performed with small piles and very small water depths, [16]. [17] established an upper threshold at $y / b=3$ beyond which the scour depth is relatively independent of the relative depth. Recent data from [18] on large piers indicated that this threshold was closer to 2. HEC-18 is the standard used by most highway agencies in USA for evaluating scour at bridges. The pier scour equation was checked using laboratory data by researchers at Colorado State University and was presented as the CSU equation in an earlier [6] publication, Highways in the River Environment. All of the data used for the original equation was for circular piers in relatively uniform fine grain sands. Correction factors were added later to account for various pier shapes, angle of attack, bed forms, and coarse bed material fractions to produce the familiar pier scour equation that is currently in HEC-18: 


$$
\frac{y_{x}}{y_{1}}=2 K_{1} K_{2} K_{2} K_{4}\left(\frac{b}{y_{1}}\right)^{0.65}\left(f_{x_{1}}\right)^{0.43}
$$

[19] defined a wide pier as one situated in shallow, low velocity flows so that $y / b<0.8$ and $F_{r}<0.8$. He isolated the data that met these conditions in the original data set used in the CSU equation and added data from other sources to derive a new equation for wide piers using the same parameters. That equation could be written as:

$$
\frac{y_{x}}{y_{1}}=2.08 K_{1} K_{2} K_{a} K_{4}\left(\frac{b}{y_{1}}\right)^{0.504}\left(f_{\mathrm{r} 1}\right)^{0.689}
$$

Then he divided the wide pier equation by the HEC-18 equation to express the difference as another correction factor, $\mathrm{K}_{\mathrm{W}}$, for the HEC-18 equation:

$$
K_{W}=1.04\left(\frac{b}{y_{1}}\right)^{-0.15}\left(f_{r=1}\right)^{0.21}
$$

Which can be applied to the HEC-18 equation when $\mathrm{y} / \mathrm{b}<0.8$ and $\mathrm{F}_{\mathrm{r}}<0.8$ in case both of these conditions were met. But if $\mathrm{y} / \mathrm{b}=0.5$ and $\mathrm{F}_{\mathrm{r}}=0.5$, which could occur, then $\mathrm{K}_{\mathrm{w}}=0.81$ which is a $19 \%$ reduction. [20] used a 2-D depth-averaged river model based on finite element theory (FESWMS) to simulate the hydraulic conditions at a contracted bridge site. The studied area was located at James River bridges near Mitchell, South Dakota. The parallel bridges were located in a crossing between the two bends of a meander. The validated model was used to examine the site characteristics that influence the concentrated flow on the right side of the main channel and the exchange of flow between the main channel and flood plains. The scour analysis was performed using the equations mentioned in [4] and a method that accounts for the soil erodibility using the curve of measured erosion rate versus shear stress.

\section{PROBLEM DESCRIPTION}

Kafr El-Zayat is a typical Egyptian city in the Delta. It is famous for its industrial and agricultural activities that contributed to the national economy of Egypt. It is located at the outer curve of a very sharp bend at Km 123 of Rosetta Branch, (Fig. 3). Field investigations were carried out to determine the local scour downstream the main bridges just after the release of the emergency flood discharge in 1998. The depth of the local scour increased from $3.0 \mathrm{~m}$ to $6.5 \mathrm{~m}$, consequently leading to bank instability in front of the city in addition to the instability of foundations of the 13 bridge piers.

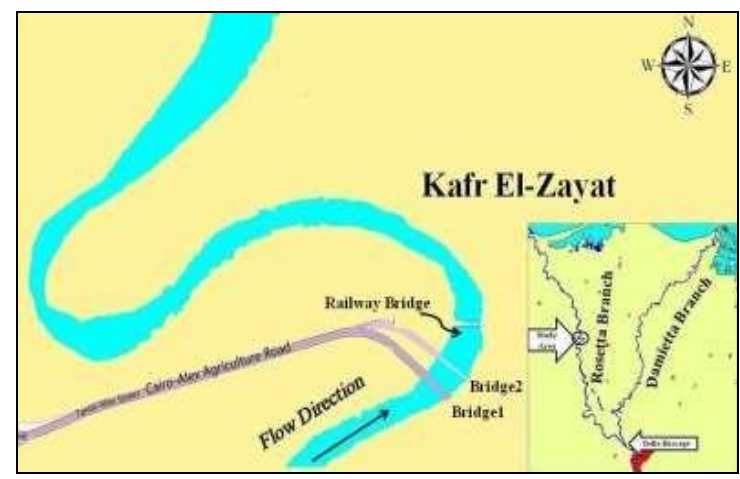

Fig. 3. Location of the study reach

The objectives of this study were to analyze and evaluate the effect of releasing high and emergency discharges downstream (H.A.D) on the existing structures of the three-bridge piers at Kafr El-Zayat City of Rosetta Branch. The potential magnitude and extent of scour occurred in the vicinity of bridge sites during flood events or in response to rapid changes in flow discharges in the river, were also evaluated. Scour evaluation including general scour, local scour, contraction scour, and bend scour were analyzed.

\section{SITE LOCATION}

Kafr El-Zayat City is located at the outer curve of a very sharp bend at Km 123 of Rosetta Branch. The study area was 9.0km long, located downstream of Delta Barrage from km 145.00 to km 154.00 downstream of El-Roda Gauge Station. The study area was a meander consisting of two successive bends at which two highway bridges and one railway bridge were located. (Fig. 4) and (Table 1) show the geometry and location of the 13 bridge piers and their distance from the left bank. 


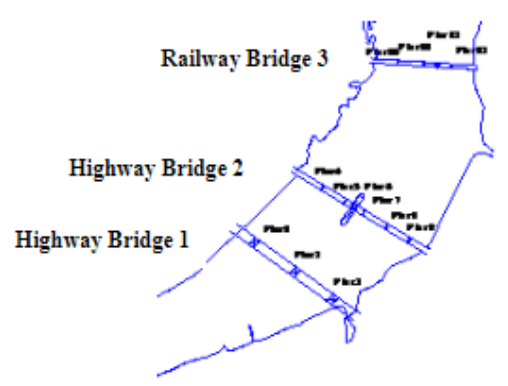

Fig.4.Piers of the bridges

Table 1.Location and dimensions of the bridge piers

\begin{tabular}{|c|c|c|c|c|c|c|c|c|c|c|c|c|c|}
\hline Bridge & \multicolumn{3}{|c|}{ Bridge 1} & \multicolumn{6}{|c|}{ Bridge 2} & \multicolumn{4}{|c|}{ Bridge 3} \\
\hline $\begin{array}{l}\text { Loc. } \\
(\mathrm{km})\end{array}$ & \multicolumn{3}{|c|}{146.00} & \multicolumn{6}{|c|}{146.239} & \multicolumn{4}{|c|}{149.682} \\
\hline $\begin{array}{l}\text { Pier } \\
\text { No. }\end{array}$ & $\begin{array}{c}\text { Pier } \\
1\end{array}$ & $\begin{array}{c}\text { Pier } \\
2\end{array}$ & $\begin{array}{c}\text { Pier } \\
3\end{array}$ & $\begin{array}{c}\text { Pier } \\
4\end{array}$ & $\begin{array}{c}\text { Pier } \\
\mathbf{5}\end{array}$ & $\begin{array}{c}\text { Pier } \\
6\end{array}$ & $\begin{array}{c}\text { Pier } \\
7\end{array}$ & $\begin{array}{c}\text { Pier } \\
8\end{array}$ & $\begin{array}{c}\text { Pier } \\
9\end{array}$ & $\begin{array}{c}\text { Pier } \\
10\end{array}$ & $\begin{array}{c}\text { Pier } \\
11\end{array}$ & $\begin{array}{c}\text { Pier } \\
12\end{array}$ & $\begin{array}{c}\text { Pier } \\
13\end{array}$ \\
\hline $\begin{array}{c}\text { Pier } \\
\text { Shape }\end{array}$ & Rec & $\operatorname{Rec}$ & $\operatorname{Rec}$ & $\operatorname{Rec}$ & $\operatorname{Rec}$ & Cir & $\operatorname{Rec}$ & $\operatorname{Rec}$ & $\operatorname{Rec}$ & $\operatorname{Rec}$ & $\operatorname{Rec}$ & Cir & $\operatorname{Rec}$ \\
\hline $\mathrm{D}(\mathrm{m})$ & $\cdots$ & -...- & $\ldots$ & ב-... & 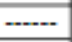 & 14.0 & 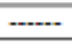 & $\ldots$ & $\ldots$ & $\ldots$ & $\cdots$ & 11.0 & $\ldots$ \\
\hline $\begin{array}{c}\text { Width } \\
(\mathrm{m})\end{array}$ & 16.0 & 16.0 & 16.0 & 4.0 & 4.0 & $\ldots$ & 4.0 & 4.0 & 4.0 & 4.0 & 4.0 & $\ldots$ & 4.0 \\
\hline $\begin{array}{l}\text { Length } \\
\text { (m) }\end{array}$ & 26.5 & 26.5 & 26.5 & 15.0 & 15.0 & $\ldots$ & 15.0 & 15.0 & 13.0 & 13.0 & 13.0 & $\cdots$ & 13.0 \\
\hline $\begin{array}{l}\text { Dist. } \\
\text { (m) }\end{array}$ & 41.2 & 182 & 300 & 77.6 & 147 & 170 & 206 & 276 & 347 & 58.1 & 132.0 & 157.6 & 195.9 \\
\hline
\end{tabular}

Where: Loc. $=$ Location downstream of El-Roda Gauge Station, D= Bridge Pier Diameter, Rec $=$ rectangular, Cir $=$ circular, Dist. $=$ distance from left bank.

\section{METHODOLOGY}

The first step in the current study was to collect the field data including surveying the water surface profile and morphological changes due to different discharge conditions along the entire reach with a total length of $9.0 \mathrm{~km}$. The prototype data were used in calibration and verification processes to determine the water depths along the entire reach of Rosetta Branch. The general and bend scour for the riverbed elevations were determined using empirical equations that were applied for the two considered scenarios in the current study. The predicted water depths were used to investigate the safety of the bridge piers against erosion under the release of high discharges.

The second step used the collected field data to feed the two-dimensional model [21] (commercial software developed by the Engineering Computer Graphics Laboratory at Brigham Young University, and the U.S. [22]). The 2-D model was used to define the flow characteristics, and the velocity distribution at Kafr ElZayat Bridges in case of different discharges. The output results from applying the 2-D model which was combined with the hydrological data and bridges characteristic data to evaluate scour and channel stability using methods outlined in HEC-18 [22], and HEC-20 [22] which are the standard methods used for evaluating scour at bridges.

\section{MODEL CONSTRUCTION}

The simulated length was about $9.0 \mathrm{~km}$, which included the 13 piers of the 3 bridges in the study. The mesh was generated for the studied area, and the bed elevations were determined using the bathymetric survey of the river. The mesh was designed by dividing the studied reach into different regions. Each region was divided into elements called quadrilateral elements and triangular elements. It should be mentioned that the designed mesh was condensed at the locations of the bridge piers to simulate the dimensions of piers with high accuracy (Fig. 5). The depth file was created based on the hydrographic survey data collected in 2006. The discharge and the water level were used as upstream and downstream boundary conditions respectively. The hydraulic roughness coefficient was defined at each grid point and ranged from 0.02 to 0.05 .

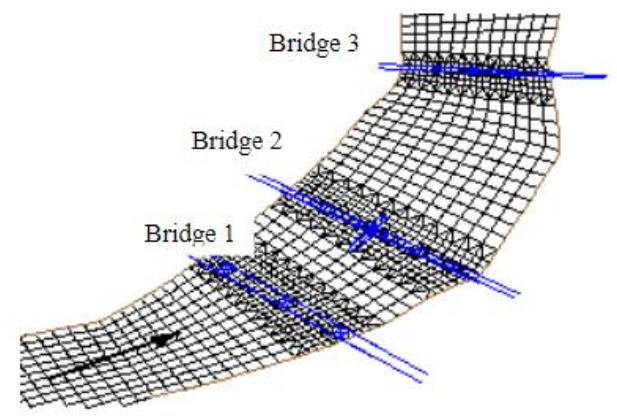

Fig. 5. Mesh generation 


\subsection{Model Calibration}

The model was run using the field hydraulic measurements in 2006 . The discharge of $222.8 \mathrm{~m}^{3} / \mathrm{sec}$ and the corresponding water level of $2.0 \mathrm{~m}$ MSL were used as upstream and downstream boundary conditions respectively. In the model calibration process, the velocity distributions were determined at 3 different cross-sections 1,2 and 3 (Fig. 6). The water surface slope was adjusted in the model by changing the roughness coefficient until a good agreement between the prototype, and model water surface slope was obtained after which the roughness coefficient was fixed. (Figs. 7, 8 and 9) as show reasonably good comparisons between the velocities obtained from the used model and field measurements taken at different cross sections.

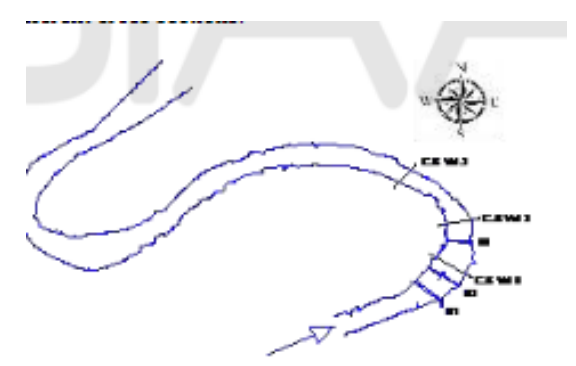

Fig. 6. Location of the calibration cross sections

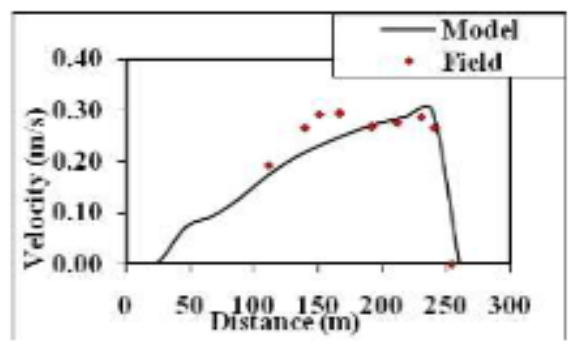

Fig. 8. Flow velocity calibration at cross section (2)

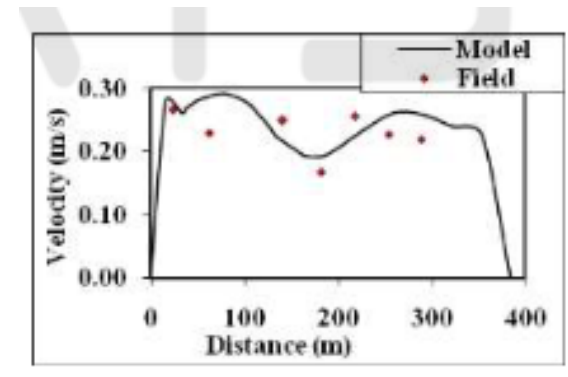

Fig. 7. Flow velocity calibration at cross section (1)

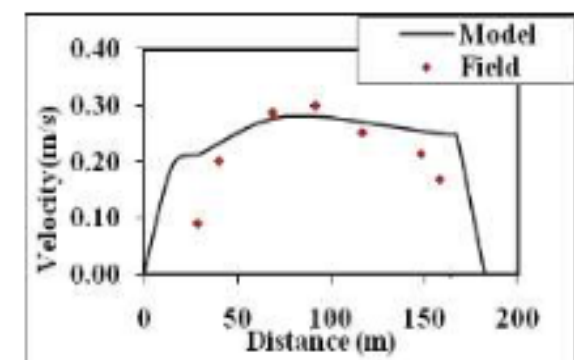

Fig. 9. Flow velocity calibration at cross section (3)

\subsection{Simulating Maximum and Emergency Flow and Results}

The high velocities cause degradation to the entire bed of the reach, particularly in the outer curve, where the city of Kafr El-Zayat is located. Consequently, the bridges' stability is expected to be at risk of foundation failure because of the scouring action. So it is required to simulate and predict the velocities at the outer curve and at bridge piers in case of high flow condition. To achieve that, the model was run for the two considered scenarios, the maximum and the emergency flow conditions. The used surveyed reach at the year of 2006 was simulated as an original case. The used boundary condition of the simulated year were as presented in (Table 2).

The model results were presented at three cross sections $\mathrm{A}-\mathrm{B}$-and $\mathrm{C}$ which are located just upstream Bridges 1, 2 and 3 respectively. The results showed that maximum velocity values along Cross Sections A, B and C were $0.76,0.80$ and $0.88 \mathrm{~m} / \mathrm{sec}$ in case of maximum flow; while in case of emergency flow the results were $1.48,1.37$ and $1.48 \mathrm{~m} / \mathrm{sec}$ respectively (Figs. 10, 11 and 12). These figures illustrate also the considered noticeable differences in velocity values in case of maximum and emergency flow conditions.

Table 2. Boundary condition

\begin{tabular}{||l|l|l||}
\hline Flow Case & Discharge $\left(\mathbf{m}^{\prime} \mathbf{m}^{\mathbf{3}} / \mathbf{d a y}\right)$ & Water Level $(\mathbf{m})$ \\
\hline \hline Maximum & 69.90 & 2.60 \\
\hline Emergency & 220.00 & 5.90 \\
\hline
\end{tabular}



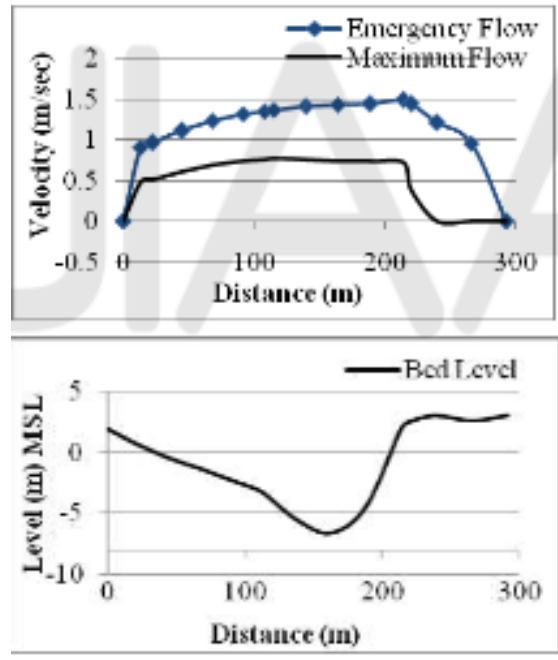

Fig.10.The velocity and bed profile at cross section a in cases of maximum and emergency flow
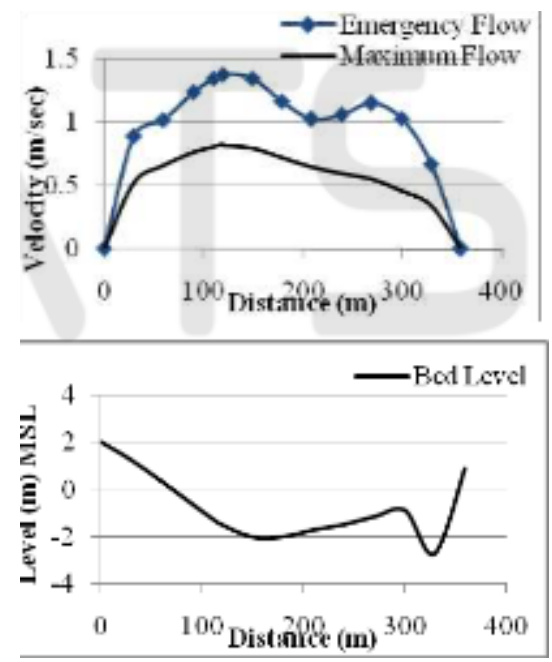

Fig.11.The velocity and bed profile at cross section $b$ in cases of maximum and emergencyflow

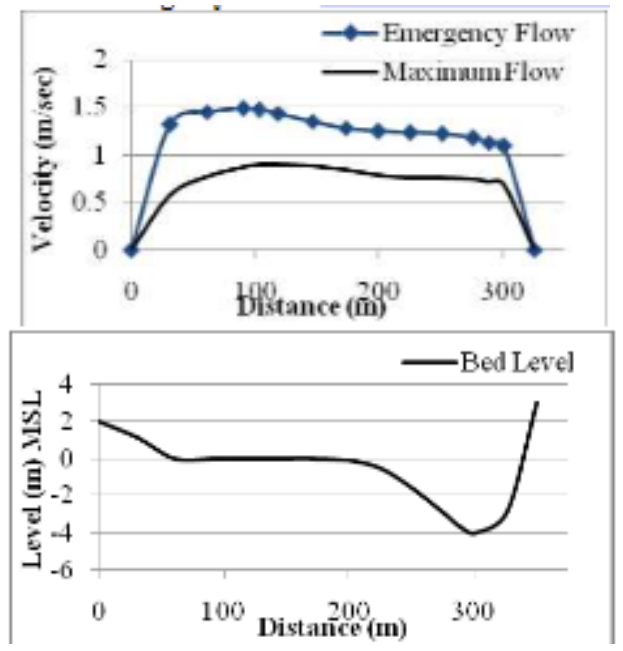

Fig.12.The velocity and bed profile at cross section $\mathrm{c}$ in cases of maximum and emergency flow

\section{SCOUR EVALUATION AND ANALYSIS}

\subsection{The Analysis Procedures}

The scour analysis was done to define the maximum scour at piers of the three bridges crossing Rosetta Branch at Kafr El-Zayat associated to the release of high flow discharges in this reach. The field measurements were combined with the hydrological data to be applied to the 2-D numerical model. The model was applied to predict the water levels and velocities for the study area under different high discharges (Fig. 13). The model results were used in addition to the procedures outlined in HEC-18 [22] and HEC-20 [22] to estimate the scour at the bridge piers considering the general scour, local scour, contraction scour, and bend scour. 


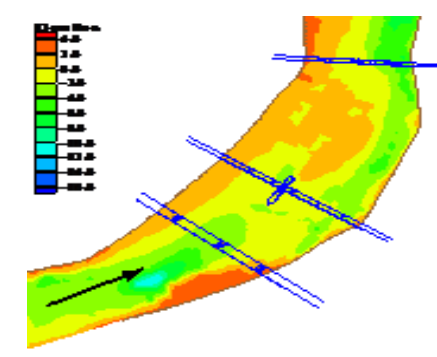

a- Bed elevations

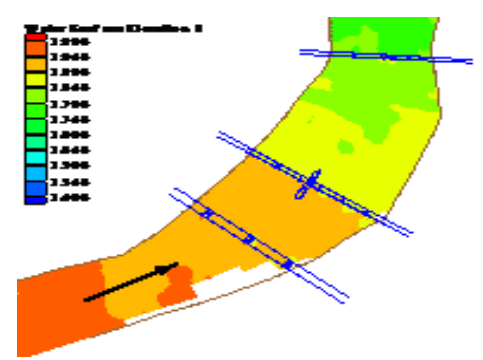

b- Water surface elevation (m)

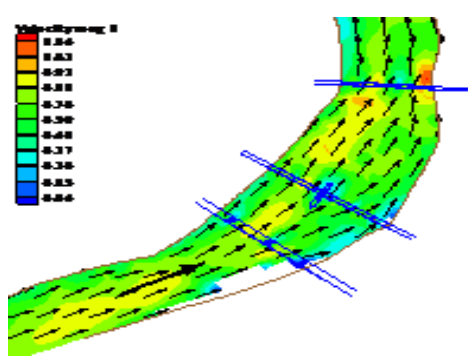

c- Velocity distribution $(\mathrm{m} / \mathrm{s})$

Fig. 13. The procedures of applying the 2-d model on the Kafr El-Zayat bridges at maximum flow conditions

\subsubsection{Local scour}

The piers' local scour hole was calculated using the hydraulic parameters based on the water velocities' magnitudes and water depths obtained from applying the 2D model in case of maximum and emergency flow at Rosetta Branch. The model results showed that Piers 2, 6 and 12 had the maximum local scour depth for each bridge (Table 3).

Table 3. Local scour for maximum and emergency flow

\begin{tabular}{|l||l|l|l||}
\hline \multicolumn{1}{|l|}{} & \multicolumn{3}{l||}{ Local Scour (m) } \\
\hline Discharge (m.m $\mathbf{3} /$ day) & Pier 2 & Pier 6 & Pier 12 \\
\hline \hline 69.90 & 9.64 & 7.48 & 6.95 \\
\hline 220.00 & 12.77 & 10.03 & 9.60 \\
\hline
\end{tabular}

\subsubsection{Contraction scour}

To predict the contraction scour, first the average approach velocities for the two considered scenarios at the studied area were estimated using the numerical model. Secondly, the critical velocities at the approaching area of the bridges were calculated using empirical equations (1) and (2), (HEC-18). From investigation of both average approach and critical velocities, it is noticed that the critical velocities were less than the average velocities. Hence the live bed contraction scour technique was used in order to estimate the contraction scour at the bridge. The contraction scour was estimated at Kafr El-Zayat Bridges as presented in (Table 4).

\subsubsection{Bend scour}

The bend scour was calculated at Kafr El-Zayat Bridges using empirical equation (4), [14]. The results are shown in (Table 4).

\subsubsection{General scour}

To define the general and bend scour at the Kafr El-Zayat bridges area, the Neil's incised equation (5) [15] was applied to the two considered high discharges, aiming at predicting the general riverbed scour, especially at the bridges area. The general scour was estimated and is also presented in (Table 4).

Table 4. General scour for maximum and emergency flow conditions

\begin{tabular}{|c|c|c|c|c|c|c|}
\hline $\begin{array}{l}\text { Bridg } \\
\text { e No. }\end{array}$ & $\begin{array}{l}\text { Discharge } \\
\text { (m.m3/day) }\end{array}$ & $\begin{array}{ll}\text { General Scour } \\
\text { by } & \text { Neil's } \\
\text { Eq(m) } & \\
\end{array}$ & $\begin{array}{l}\text { Bend } \\
\text { scour } \\
(\mathbf{m}) \\
\end{array}$ & $\begin{array}{l}\text { Contractio } \\
\text { n Scour } \\
(\mathbf{m}) \\
\end{array}$ & $\begin{array}{l}\text { Bend }+ \\
\text { Contraction } \\
\text { Scour }(\mathbf{m}) \\
\end{array}$ & $\begin{array}{l}\text { Considered } \\
\text { General Scour } \\
(\mathbf{m})\end{array}$ \\
\hline \multirow{2}{*}{$\begin{array}{l}\text { Bridg } \\
\text { e } 1\end{array}$} & 69.90 & 2.70 & 3.86 & 0.48 & 4.34 & 4.34 \\
\hline & 220.00 & 4.50 & 4.10 & 0.87 & 4.97 & 4.97 \\
\hline \multirow{2}{*}{$\begin{array}{l}\text { Bridg } \\
\text { e } 2\end{array}$} & 69.90 & 2.58 & 2.60 & 0.25 & 2.85 & 2.85 \\
\hline & 220.00 & 3.90 & 2.90 & 0.41 & 3.31 & 3.90 \\
\hline \multirow{2}{*}{$\begin{array}{l}\text { Bridg } \\
\text { e } 3\end{array}$} & 69.90 & 3.30 & 5.35 & 0.34 & 5.69 & 5.69 \\
\hline & 220.00 & 5.10 & 5.17 & 0.57 & 5.74 & 5.74 \\
\hline
\end{tabular}

Where: Considered General Scour $(\mathrm{m})=$ The higher value between Neill's equation bend scour and the contraction scour plus the bend scour [15].

\subsection{Evaluation of Total Scour}

The total scour can be expressed as the summation of the general, local, contraction and bend scours.

The total scour was evaluated in the following equation:

Total Scour $=$ General Scour + Local Scour + Contraction Scour + Bend Scour.

The predicted flow pattern at the Kafr El-Zayat studied bridges area indicated that the values of bend scour were significant due to the meandering pattern in this area of river reach. The magnitudes of total scour are presented in (Table 5). (Fig. 14) shows the evaluation of the total scour at Kafr El-Zayat bridge piers. The maximum expected scour for all 
piers were estimated. It was found that Piers 2, 6 and 12 had a maximum scour depth. (Figures 15, 16 and 17) show the location of the bridge piers.

Table 5. Total scour at the bridges

\begin{tabular}{||l|l|l|l|l|l||}
\hline $\begin{array}{l}\text { Bridge } \\
\text { No. }\end{array}$ & $\begin{array}{l}\text { Pier } \\
\text { No. }\end{array}$ & Discharge(m.m³/day) & $\begin{array}{l}\text { General } \\
\text { Scour(m) }\end{array}$ & $\begin{array}{l}\text { Local } \\
\text { Scour(m) }\end{array}$ & $\begin{array}{l}\text { Total } \\
\text { Scour(m) }\end{array}$ \\
\hline \hline \multirow{2}{*}{ Bridge 1 } & \multirow{2}{*}{ Pier 2 } & 69.90 & 4.34 & 9.64 & 13.98 \\
\cline { 3 - 6 } & 220.00 & 4.97 & 12.77 & 17.74 \\
\hline \multirow{2}{*}{ Bridge 2 } & \multirow{2}{*}{ Pier 6 } & 69.90 & 2.85 & 7.48 & 10.33 \\
\cline { 3 - 6 } & 220.00 & 3.90 & 10.03 & 13.93 \\
\hline Bridge 3 & \multirow{2}{*}{\begin{tabular}{l} 
Pier \\
\cline { 3 - 6 }
\end{tabular}} & 69.90 & 5.69 & 6.95 & 12.64 \\
\hline \hline \multicolumn{2}{|l|}{5.74} & 9.60 & 15.34 \\
\hline
\end{tabular}

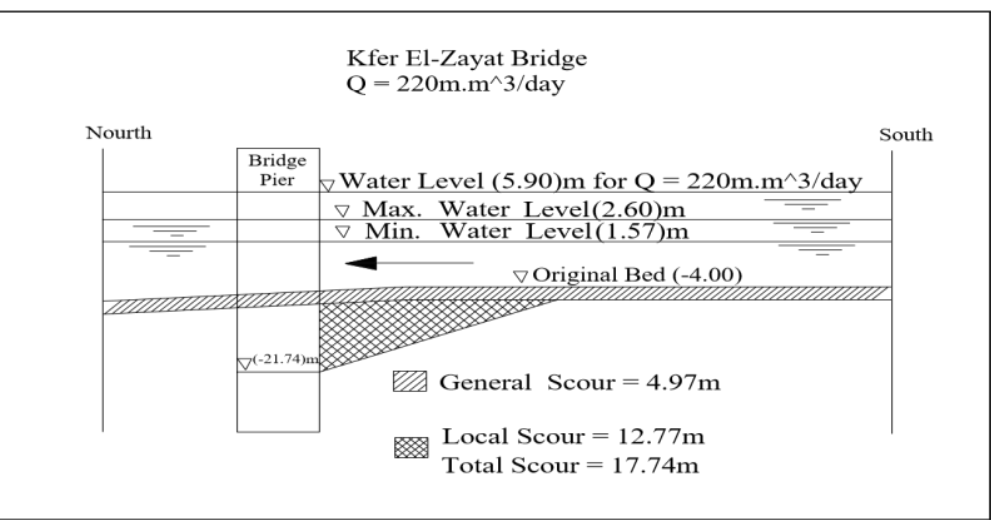

Fig. 14. Evaluation of the total scour at Kafr El-Zayat

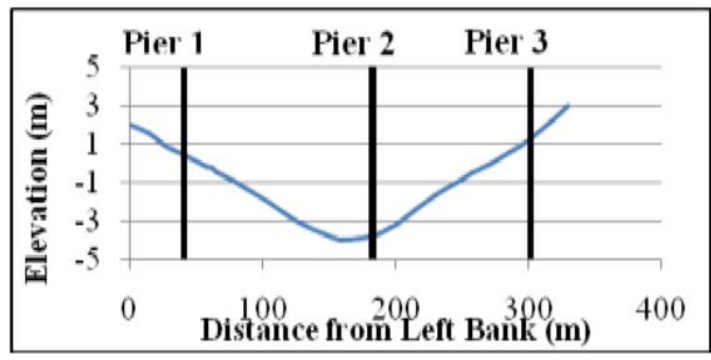

Fig. 15. First bridge piers location

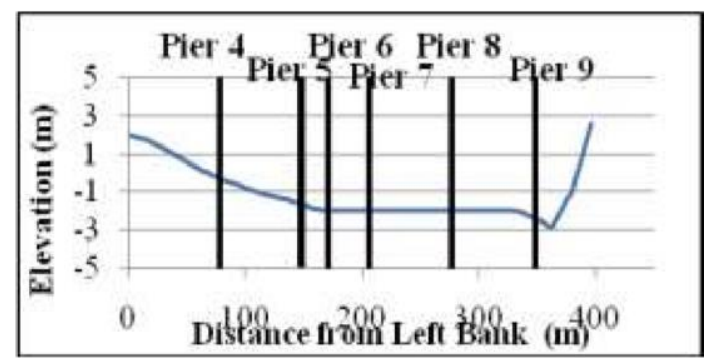

Fig. 16. Second bridge piers location

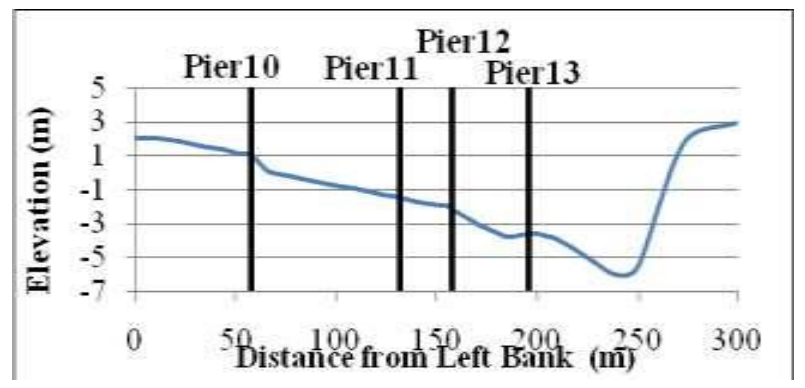

Fig. 17. Third bridge piers location

\section{CONCLUSION}

The present study was carried out to analyze and evaluate the effect of releasing high discharges $\left(69.90,220.00 \mathrm{~m} . \mathrm{m}^{3} / \mathrm{day}\right)$ on the existing structures by using a 2-D numerical model and empirical equations to predict the scour around bridge piers. The following main conclusions may be drawn:

1. Unexpected velocity profiles resulted in some cross sections were appeared due to the human interference.

2. The maximum scour depth was directly proportional to discharge.

3. The increase of the scour hole around the piers of the first bridge was higher than the increase of the scour hole around the piers of the second and third bridges.

4. The local scour around the bridge piers estimated by the 2-D numerical model gave higher scour values than the general scour (Neil's equation) under the same conditions. 
5. The scour around the bridge piers calculated by the scour bend equation [14] gave higher scour values than both general scour equation (Neil's equation) and contraction scour.

6. Contraction scour results gave the lowest scour values when compared to the other types of scours.

\section{LIST OFSYMBOLS}

$\mathrm{V}_{\mathrm{C}}=$ Critical velocity

$\mathrm{y}_{\mathrm{a}}=$ Average depth of flow upstream of the bridge.

$\mathrm{D}_{50}=$ Particle size in a mixture in which $50 \%$ are smaller.

$\mathrm{Y}_{\mathrm{s}} \quad=$ Average depth of scour.

$\mathrm{Y}_{0}=$ Average depth of flow in the contracted section before scour.

$\mathrm{Y}_{1}=$ Depth of flow in the upstream of bridge.

$\mathrm{Y}_{2}=$ Depth of flow in the contracted section.

$\mathrm{V}_{\mathrm{c}} \quad=$ Critical velocity.

$\mathrm{W}_{1}=$ Bottom width upstream of bridge.

$\mathrm{W}_{2}=$ Bottom width in the contracted section.

$\mathrm{Q}_{1} \quad=$ Flow in the upstream of bridge transporting sediment.

$\mathrm{Q}_{2}=$ Flow in the contracted section.

$\mathrm{K}_{1} \quad=$ Exponent depending upon the mode of bed material transport.

$\mathrm{Q}=$ Discharge through the bridge.

$\mathrm{D}_{\mathrm{m}}=$ Diameter of the smallest non-transportable particle in the bed material $(1.25 \mathrm{xD} 50)$ in the contracted section.

$\mathrm{W}=$ Bottom width of the contracted section less pier width.

$\mathrm{y}_{0}=$ Average existing depth in the contracted section.

$\mathrm{Z}_{\mathrm{bs}}=$ Bend scour component of total scour depth.

$\mathrm{V}=$ Velocity of upstream flow.

$\mathrm{y} \quad=$ Maximum depth of upstream flow.

$\mathrm{Y}_{\mathrm{h}}=$ Hydraulic depth of upstream flow.

$\mathrm{Se} \quad=$ Upstream energy slope.

a $\quad=$ Angle formed by the projection of the channel centerline from the point of curvature to a point which meets a line tangent to the outer bank of the channel.

$\mathrm{y}_{\mathrm{gs}}=$ General scour depth.

$\mathrm{d}_{\mathrm{f}} \quad=$ Scoured depth below design floodwater level.

$\mathrm{d}_{\mathrm{i}}=$ Average depth at bankfull discharge in incised reach.

$\mathrm{q}_{\mathrm{f}} \quad=$ Design flood discharge per unit width.

$\mathrm{q}_{\mathrm{i}}=$ Bankfull discharge in incised reach per unit width.

$\mathrm{m}=$ Exponent varying from 0.67 for sand to 0.85 for coarse gravel.

$\mathrm{Z}=$ Multiplying factor ( 0.5 for straight reach, 0.6 for moderate bend, 0.7 for severe bend).

$\mathrm{y}_{\mathrm{s}}=$ Equilibrium scour depth.

$\mathrm{y}_{1}=$ Flow depth.

$\mathrm{b}=$ Pier width.

$\mathrm{F}_{\mathrm{r} 1}=$ Froude number directly upstream of the pier

$\mathrm{KW}=$ Means there would be a $5 \%$ reduction in the estimated scour depth approximately 0.95 .

$\mathrm{K}_{1}, \mathrm{~K}_{2}, \mathrm{~K}_{3}$, and $\mathrm{K}_{4} \quad=$ Correction factors.

$[\mathrm{ft} / \mathrm{s}]$

[ft]

[ft]

[ft]

[ft]

[ft]

[ft]

$[\mathrm{ft} / \mathrm{s}]$

[ft]

[ft]

$[\mathrm{f} / \mathrm{s}]$

$\left[\mathrm{f}^{3} / \mathrm{s}\right]$

$[\mathrm{ft}]$

$[\mathrm{ft}]$

$[\mathrm{ft} / \mathrm{s}]$

[ft]

[ft]

$[\mathrm{ft} / \mathrm{ft}]$

[degrees

]

[ft]

[ft]

[cfs/ft]

[cfs/ft]

\section{REFERENCES}

[1].Hydraulic Research Institute (HRI), "Protection of Bank against Erosion along the River Nile". Report No. (3), Cairo, Egypt, 2005.

[2].River Nile Development Project (RNDP), Ministry of Public Works and Water Resources, Egypt, 1991a, $1992 \mathrm{~b}$.

[3].Jean-Louis Briaud, Hamn-Ching Chen, Kuang-An Chang, Young-An Chung, Namgyu Park, Wei Wang, and Po-Hung Yeh, "Establish Guidance for Soils Properties Based-Prediction of Meander Migration Rate". Zachry Department of Civil Engineering, Texas A\&M University, 2007.

[4].Hydraulic Engineering Circular 18. Fifth Edition, "Evaluating Scour at Bridges". FHWA HIF 12 003 HEC-18, Federal Highway Administration. U.S. Department of Transportation. Washington D.C., 2012.

[5].Flood Control District of Maricopa County (FCDMC), "River Mechanics Manual for DDMSW". Draft, 2009.

[6].Federal Highway Administration (FHWA), "Evaluating Scour at Bridges". Hydraulic Engineering Circular, Number (18), (HEC-18), 2001.

[7].Flood Control District of Maricopa County (FCDMC), "Drainage Design Manual for Maricopa County". Draft: Chapter (11), 2007.

[8].Melville, B.W., "Local Scour at Bridge Sites". Report No. (117), University of Auckland, School of Engineering, Auckland, New Zealand, 1975.

[9].Shen, H.W., Schneider, V.R. andKaraki, S.S., "Mechanics of Local Scour". Colorado State University, Civil Engineering Dept., Fort Collins, Colorado, Pub. No. (CER66-HWS22), 1966.

[10]. Sheppard, D. M., "An Overlooked Local Sediment Scour Mechanism". Proceedings of the 83rd Meeting of the Transportation Research Board, Washington D.C., published in the J. of the Transportation Research Board, Transportation Research Record. No. (1890), pp. 107-111, January 11-15, 2004. 
[11]. Lança, R., Fael, C., Maia, R., Pêgo, J., and Cardoso, A., "Clear-Water Scour at Comparatively Large Cylindrical Piers", ASCE. Journal of the Hydraulic Division, Vol. (139), Issue (11), 2013..

[12]. Hager, W. and Unger, J., "Bridge Pier Scour under Flood Waves". ASCE, Journal of the Hydraulic Division, Vol. (136), Issue (10), 2010.

[13]. Sheppard, D., Melville, B., and Demir, H., "Evaluation of Existing Equations for Local Scour at Bridge Piers". ASCE, Journal of the Hydraulic Division, Vol. (140), Issue (1), 2014.

[14]. Simons, Li \& Assoc. (SLA), "Standards Manual for Drainage Design and Floodplain Management in Tucson". Arizona. Prepared for City of Tucson, Department of Transportation. Engineering Division, 1989b (revised July, 1998).

[15]. Pemberton, E.L. and Lara, J.M., "Computing Degradation and Local Scour". U.S. Bureau of Reclamation. Sedimentation section, Denver CO., 1984.

[16]. Ettema, R., "Scour at Bridge Piers". Dissertation, Department of Civil Engineering, University of Auckland, New Zealand, 1980.

[17]. Melville, B.W. and Sutherland, A.J., "Design Method for Local Scour at Bridge Piers", ASCE. Journal of the Hydraulic Division. Vol. (114), No. (10), Oct. 1988.

[18]. Jones, J. Sterling and D. Max Sheppard, "Scour at Wide Piers", Proceedings for the 2000 Joint Conference on Water Resources Engineering and Water Resources Planning and Management Conference. Minneapolis. MN. July 30August 2, 2000.

[19]. Johnson, Peggy A., "Scour at Wide Piers Relative to Flow Depth. Stream Stability and Scour at Highway Bridges", Compendium of ASCE conference papers edited by E. V. Richardson and P. F. Lagasse. pp 280 . $287,1999$.

[20]. Rossell, R. and Ting, F., " Hydraulic and Contraction Scour Analysis of a Meandering Channel" James River Bridges near Mitchell, South Dakota. J. Hydraul. Eng., 139 (12), 1286-1296, 2013.

[21]. SMS, "Surface Water Modeling System. Reference Manual", version 8.0. Brigham. Young University. Engineering Computer Graphics Laboratory. Provo, Utah, 2002.

[22]. Federal Highway Administration, "Scour ability of Rock Formations. U.S. Department of Transportation Memorandum", HNG-31. Washington D.C. R5, 1991. 